\title{
MILIARY TUBERCULOSIS COMPLICATED BY STAPHYLOCOCCAL SEPSIS
}

\author{
Dragan Stanojevic 1 , Gordana Antonijevic², Radisa Vojinovic 3,4 , Valentina Opancina ${ }^{3,4}$ \\ ISpecial Hospital for Nonspecific Lung Diseases "Sokobanja", Sokobanja, Serbia \\ 2Special Hospital for Lung Diseases "Ozren", Sokobanja, Serbia \\ ${ }^{3}$ Faculty of Medical Sciences, Department of Radiology, University of Kragujevac, Kragujevac, Serbia \\ ${ }^{4}$ Clinical Center Kragujevac, Department of Radiology, Kragujevac, Serbia
}

\section{МИЛИЈАРНА ТУБЕРКУЛОЗА КОМПЛИКОВАНА СТАФИЛОКОКНОМ СЕПСОМ}

\author{
Драган Станојевић1, Гордана Антонијевић², Радиша Војиновић,4, Валентина Опанчина 3,4 \\ ${ }^{1}$ Спещијална болница за неспецифичне плућне болести „Сокобања“, Сокобања \\ ${ }^{2}$ Спеиијална болница за плућне болести „Озрен“, Сокобања \\ ЗФакултет медицинских наука, Катедра за радиологију, Универзитет у Крагујевиу, Крагујеваи \\ ${ }^{4}$ Клинички иентар Крагујеваи, Служба за радиолошку дијагностику, Крагујевач
}

\begin{abstract}
Milliary tuberculosis is potentially fatal due to the massive dissemination of Mycobacterium tuberculosis. Since immunoregulatory mechanisms are disrupted, during the evolution of milliary tuberculosis, nonspecific infections develop and sometimes even sepsis. Sepsis is a rare complication in immunocompetent patient. In patients with disseminated tuberculosis, close attention and care should be made if clinical presentation suggests sepsis.

In this paper, we present a patient with whom we simultaneously diagnosed miliary tuberculosis and staphylococcal sepsis on admission in 2007. Miliary tuberculosis was first proven histopathologically by transbronchial lung biopsy, and later confirmed by microbiological and ophthalmologic examination. Two blood samples from different punction locations had isolated Staphylococcus epidermidis. Right after the admission, medical team started a treatment of septic shock and respiratory failure with the oxygen therapy, parenteral rehydration, vasoactive agents with a combination of selected antibiotics and antituberculotic drugs. After recovery, the treatment was continued in extensive phase using combination of antituberculotics and patient was discharged to be home treated and checked in an antituberculous ambulant.
\end{abstract}

Key words: tuberculosis, miliary; sepsis; Staphylococcus epidermidis.

\section{INTRODUCTION}

Tuberculosis (TB) is a chronic infectious disease that represents an important cause of death in undeveloped and developing countries (1). The incidence of TB in Serbia has been declining since 1990 and current data of the national Institute of Public Health in Belgrade report the actual incidence rate for TB to be 15.61 per 100000 persons (2). Milliary tuberculosis is potentially fatal due to the massive dissemination of Mycobacterium tuberculosis (M). If the bacilli go to the lymph circulation or to

\section{САЖЕТАК}

Милијарна туберкулоза је потенцијално фатална због масивне дисеминачије Mycobacterium tuberculosis. Пошто су имунорегулаторни механизми поремећени, током еволуиије милијарне туберкулозе развијају се неспецифичне инфекиије, а понекад чак и сепса. Cепса је ретка компликација код имунокомпетентног пацијента. Код пацијената с дисеминованом туберкулозом треба обратити пажну и спровести посебну негу ако клиничка презентаиија указује на сепсу. У овом раду представљамо пацијента код кога смо у исто време доказали постојање милијарне туберкулозе и стафилококне сепсе на пријему 2007. године. Прво смо дијагностиковали милијарну туберкулозу хистопатолошки путем трансбронхијалне биопсије, а након тога потврдили микробиолошким и офталмолошким прегледом. Два крвна узорка за хемокултуру са различитих локација пункција изоловале cy Staphylococcus epidermidis. Одмах након пријема, медицински тим је започео лечење септичког шока и респираторне инсуфицијениије применом оксигенотерапије, парентералне рехидраџије, вазоактивних агенса уз одабрану комбиначију антибиотика и антитуберкулотика. Третман се наставио у екстензивној фази коришћењем комбинације антитуберкулотика и пацијент је отпуштен да се лечи код куће и долази на контроле у антитуберкулозну амбуланту.

Кључне речи: туберкулоза, милијарна; сепса; Staphylococcus epidermidis.

pulmonary arteries, they will spread mainly all over lungs, but if they go to the pulmonary veins, they will arrive to systemic blood circulation and then generalized milliary tuberculosis would be presented (3). Since immunoregulatory mechanisms are disrupted, during the evolution of milliary tuberculosis, nonspecific infections develop and sometimes even sepsis. When these two systemic infections happen simultaneously, treatment is more difficult, and prognosis is worse (4). A rare complication of Mycobacterium tuberculosis infection, 
severe sepsis, is associated with septic shock with multiorgan dysfunction (5). Sepsis develops from a range of bacteria present in the blood when the immune system is compromised (6).

In this paper, we present a patient with miliary tuberculosis and staphylococcal sepsis caused by Staphylococcus epidermidis.

\section{CASE REPORT}

A male patient, 50 years old was admitted to the Special Hospital for Lung Diseases "Ozren" in Sokobanja on September 12th 2007. The patient was a smoker and a chronic alcoholic. Three months prior to the admission he started dry coughing, lost $10 \mathrm{~kg}$ of body weight, had appetite loss, fatigue and fever up to $38^{\circ} \mathrm{C}$. These symptoms indicated tuberculosis, since the patient had diagnosis of pulmonary tuberculosis that was treated for 9 months in 1992.

On admission in our hospital, physical examination displayed cachexia, paleness, hypothermia $\left(35.8{ }^{\circ} \mathrm{C}\right.$ degrees Celsius), dyspnea, tachypnea, central cyanosis, dehidratation, oliguria, hypotension (blood pressure was $60 / 40 \mathrm{mmHg}$ ), tachycardia (heart rate was 110 beats per min) and a passive posture. Neurologic examination was in the range of normal. Pulmonary auscultation showed bilaterally decreased respiratory sound. Blood analysis results showed low sedimentation rate, "calm" leukocytes with granulocytosis, hyperbilirubinaemia, hypokalemia and severe hypoproteinaemia and hypoalbuminaemia (Table 1). Arterial blood gas analysis and acid-base balance have shown hypoxemic respiratory failure and lactic acidosis, which is seen in Table 1. Tuberculin test (Mantoux) was negative. Microbiological sputum examination did not identify nonspecific pathogens. Three consecutive sputum samples stained by Ziehl-Neelsen were negative for acid-fast bacilli (Mycobacteria). Acidfast bacilli smear and culture of blood and urine did not demonstrate the presence of $\mathrm{M}$. Chest X-rays demonstrated wide spread small-miliary (2-4mm) nodular opacities distributed throughout both lungs with late TB sequelae in the upper lung fields, predominantly left (Figure 1). Fiberoptic bronchoscopy (Olympus BF TE2) with transbronchial biopsy (TBB) under fluoroscopic navigation was performed in topical anesthesia and only cracked narrow of lingular bronchus was seen. After five days from the bronchoscopy, histopathological finding of TBB was: "Bronchitis granulomatosa specifica, verosimiliter tuberculosis productive". Also, postbronchoscopic sputum was acid-fast bacilli positive. Ophthalmologic examination showed chorioretinal infiltration with productive miliary nodules ("Chorioretinitis miliaris tuberculosa"). At the same time we performed haemoculture procedure, and two blood samples from different punction locations had isolated Staphylococcus epidermidis. Right after the admission, medical team started treatment of septic shock and respiratory failure with the oxygen therapy, parenteral rehydration with crystalloid fluid replacement, vasoactive agents (Dopamine infusion) and supportive care. Hemoculture results indicated combined antibiotic treatment (ceftriaxone 4.0 gr IV per day in 2 divided doses, ciprofloxacin $400 \mathrm{mg}$ IV per day). Simultaneously

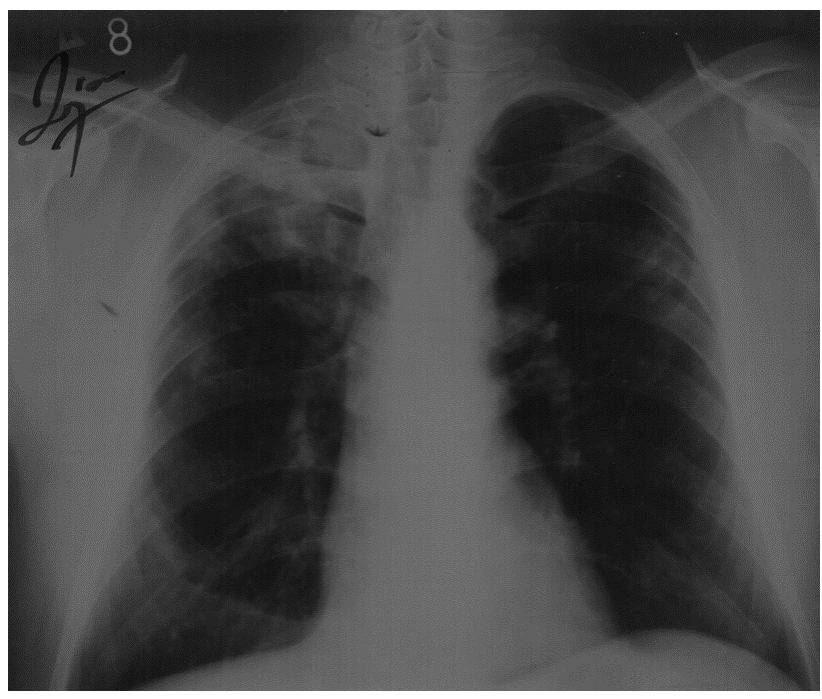

Figure 1. Chest radiography made in 2002 showed consolidations in right upper and mid lung lobe and left mid lobe.

Table 1. Laboratory blood test results, arterial blood gas analysis and acid-base balance on admission

\begin{tabular}{|l|c|l|c|}
\hline Variable & Value & Variable & Value \\
\hline Sedimentation rate & $2 / 4 \mathrm{~mm} / \mathrm{h}$ & Total bilirubin & $23.8 \mu \mathrm{moll} / \mathrm{L}$ \\
\hline Leykocite number & $8.8 \times 10^{9} / \mathrm{L}$ & Direct bilirubin & $8.2 \mu \mathrm{mol} / \mathrm{L}$ \\
\hline Granulocite percet & $73 \%$ & Total serum protein & $48 \mathrm{~g} / \mathrm{L}$ \\
\hline Alanine aminotransferase(ALT) & $50 \mathrm{U} / \mathrm{L}$ & Serum albumin & $24.6 \mathrm{~g} / \mathrm{L}$ \\
\hline Potassium(K) & $3.1 \mathrm{mmoll} / \mathrm{L}$ & Bicarbonate $(\mathrm{HCO} 3)$ & $19 \mathrm{mmol} / \mathrm{L}$ \\
\hline Partial pressure of oxygen $(\mathrm{PO} 2)$ & $6.1 \mathrm{kPa}$ & $\begin{array}{l}\text { Partial pressure of carbon } \\
\text { dioxide }(\mathrm{PCO} 2)\end{array}$ & $3.9 \mathrm{kPa}$ \\
\hline $\begin{array}{l}\text { Oxygen saturation in arterial } \\
\text { blood }(\mathrm{SaO} 2)\end{array}$ & $86 \%$ & Lactate & $17 \mathrm{mmol} / \mathrm{l}$ \\
\hline Acidity $(\mathrm{pH})$ & 7.30 & Base deficit & $-4.7 \mathrm{mmol} / \mathrm{L}$ \\
\hline
\end{tabular}




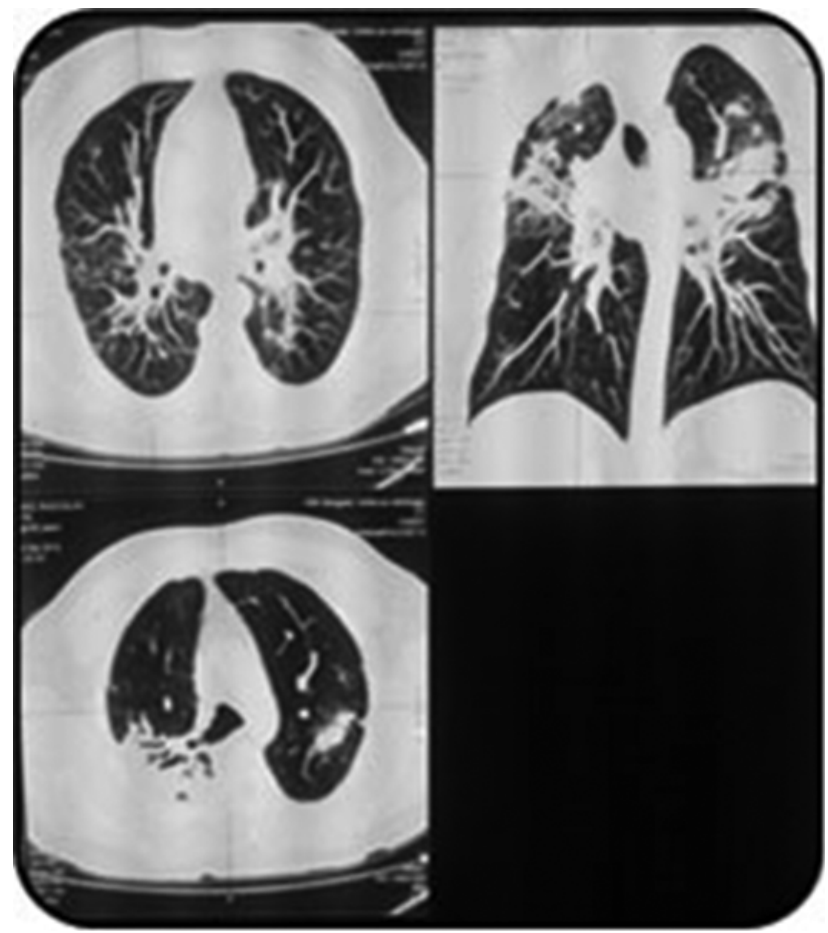

Figure 2. CT scan of thorax, made in 2010. It showed progression of lung lesions with mediastinal lymphadenopathy which suggested chronic sarcoidosis

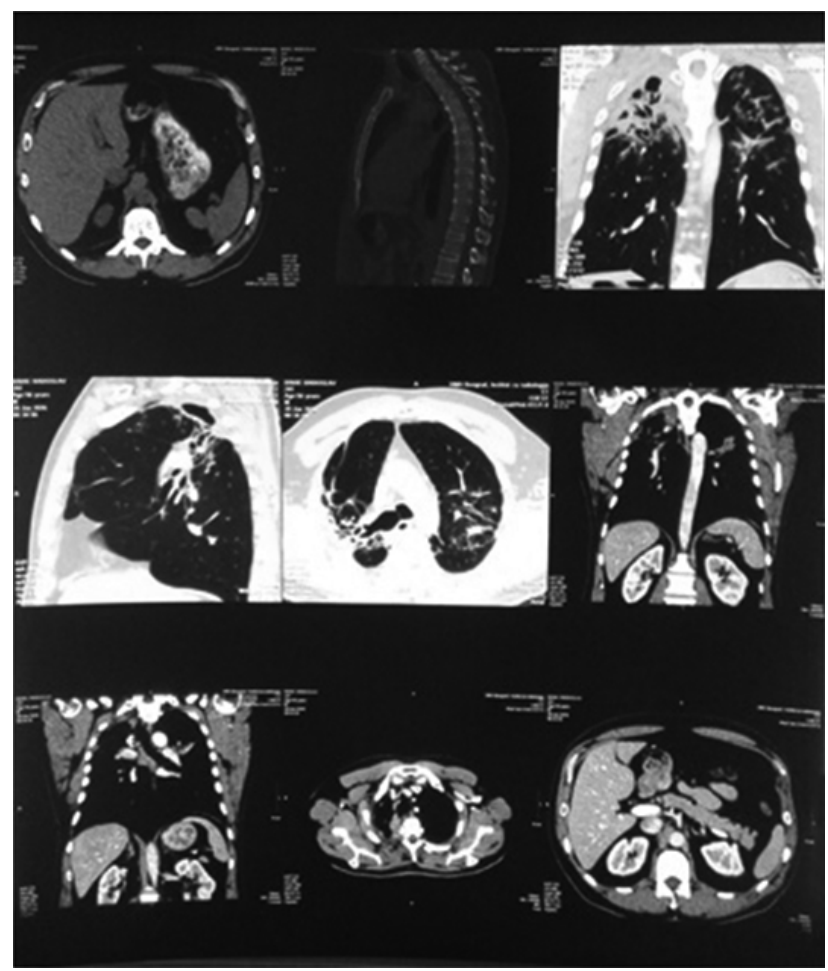

Figure 3. CT scan of thorax and abdomen from 2016. It showed cystic bronchiectasis with fibrosis in the right upper lung which shifted the trachea the into right side. In both lower lobes fibrous changes of lower degree were seen. Mediastinal lymph nodes were enlarged, the biggest was right paratracheal node $(26 \mathrm{~mm})$ and infracarineal $(20 \mathrm{~mm})$. the patient started receiving antituberculotics (isoniazid $(\mathrm{H})$, rifampicin $(\mathrm{R})$, pyrazinamide $(\mathrm{Z})$, streptomycin $(\mathrm{S})$ and ethambutol (E)) by protocol for tuberculosis relapse. Also, blood plasma was applied. Treatment of antibiotics for 2 weeks and antituberculotics for one month gave good results, the patient started recovering, gas analysis was improving as well as sedimentation rate and leucocyte number, which were good prognostic signs. Also, after initial hypothermia, patient had septic fever during the first month and after that subfebrile fever during the next month. After incubation period ( 8 weeks), LowensteinJensen medium of sputum had 5 isolated colonies of Mycobacterium tuberculosis, so the diagnosis of pulmonary tuberculosis was confirmed. After the initial phase of antituberculotic treatment (2 months HRZSE, then 1 month HRZE), the patient recovered clinically, gained weight and had no fever. Chest radiography showed good regression, with numerous sequelae in both lungs (Figure 2.) and bacteriological conversion of sputum was made. The treatment was continued in extensive phase using a combination of antituberculotics (5 mounts HRE) and the patient was discharged to be home treated and checked by antituberculous ambulant.

\section{DISCUSSION}

Our patient presented with miliary tuberculosis and sepsis which was due to the immunosuppression. However, literature search suggested us that this was a very rare complication of disseminated tuberculosis. It is described in patients with serious immunosuppression, most commonly in acquired immune deficiency syndrome. There is a small number of described case reports of patients with miliary TB and sepsis (5).

One of the reports described TB bacteremia and death of a middle-aged male, without hypotension or respiratory failure (7). Other author described a 69-year-old female with clinical presentation of sepsis which led to septic shock and consequently to death. After death, Mycobacterium tuberculosis was proven in sputum and ascitic fluid (8). It is described that in patients with TB and sepsis, septic shock is being caused by lipoarabinomannan production of tumor necrosis factor (5). After the literature search we found only two cases of tuberculosis and sepsis causes by $\mathrm{S}$. epidermidis $(9,10)$. However, it is also described that S.epidermidis causes great sepsis in great number of neonates (11). Even though it is usually considered as harmless, $\mathrm{S}$. epidermidis is also an important pathogen in surgical patients with critical condition (12).

\section{CONCLUSION}

Staphylococcal sepsis is a rare complication in immunocompetent patient. In patients with disseminated 
tuberculosis, close attention and care should be made if clinical presentation suggests sepsis. Prompt diagnosis and complex therapy and care provides a good prognosis.

\section{ABBREVIATIONS}

Tuberculosis (TB), Mycobacterium tuberculosis (M), transbronchial biopsy (TBB), isoniazid $(\mathrm{H})$, rifampicin (R), pyrazinamide (Z), streptomycin (S) and ethambutol(E)

\section{REFERENCES}

1. Savic I, Trifunovic-Skodric V, Mitrovic D. Clinically unrecognized miliary tuberculosis: an autopsy study. Ann Saudi Med 2016; 36:42-50.

2. Health Statistics Statistical Yearbook of the Republic of Serbia. Belgrade: Institute for Public Health "Dr Milan Jovanovic Batut", 2012. (in Serbian).

3. Silva R, Jara J, Soto T, Sepúlveda P. Severe disseminated tuberculosis in a patient on immunosuppressive treatment. Report of one case. Rev Med Chil 2011; 139:774-8. (in Spanish).

4. Jacob JT, Mehta AK, Leonard MK. Acute forms of tuberculosis in adults. Am J Med 2009; 122:12-7.

5. Bridges DA, Bedimo RG. Severe tuberculosis sepsis in an immunocompetent patient. Am J Med 2006; 119:e11-4.
6. Otto M. Staphylococcus epidermidis: a major player in bacterial sepsis? Future Microbiol 2017; 12:1031-3.

7. Hadad DJ, Pignatari AC, Machado MA, Telles MA. Mycobacterium tuberculosis bacterium diagnosed in an HIV-negative patient in Brazil: a rare or an underreported event? Braz J Infect Dis 2004; 8:184-5.

8. Pene F, Papo T, Brudy-Gulphe L, et al. Septic shock and thrombotic microangiopathy due to Mycobacterium tuberculosis in a nonimmunocompromised patient. Arch Intern Med 2001; 161:1347-8.

9. Adamovich VN, Kaliuk AN. Staphylococcal bacteremia in tuberculosis. Klin Med (Mosk) 1983; 61:40-4. (in Russian).

10. Kuriya N, Fukuda T, Eguchi K, Miyake S, Nagataki S. Disseminated bone tuberculosis with osteomyelitis and septicemia caused by Staphylococcus epidermis. Report of a case. Nihon Naika Gakkai Zasshi 1984; 73:653-8. (in Japanese).

11. Dong Y, Speer CP, Glaser K. Beyond sepsis: Staphylococcus epidermidis is an underestimated but significant contributor to neonatal morbidity. Virulence 2018; 9:621-33.

12. Burchard KW, Minor LB, Slotman GJ, Gann DS. Staphylococcus epidermidis sepsis in surgical patients. Arch Surg 1984; 119:96-100. 